\title{
The Relationship between Macroeconomic Variables and Passenger Vehicle Sales in Malaysia
}

Fidlizan Muhammad (corresponding author)

Department of Economics, Faculty of Management and Economics

Universiti Pendidikan Sultan Idris, Perak, Malaysia

E-mail: fidlizan@fpe.upsi.edu.my

Mohd Yahya Mohd Hussin

Department of Economics, Faculty of Management and Economics

Universiti Pendidikan Sultan Idris, Perak, Malaysia

E-mail: yahya@fpe.upsi.edu.my

Azila Abdul Razak

Department of Economics, Faculty of Management and Economics

Universiti Pendidikan Sultan Idris, Perak, Malaysia

E-mail: azila@fpe.upsi.edu.my

Norimah Rambeli

Department of Economics, Faculty of Management and Economics

Universiti Pendidikan Sultan Idris, Perak, Malaysia

E-mail: norimah@fpe.upsi.edu.my

Gan Pei Tha

Department of Economics, Faculty of Management and Economics

Universiti Pendidikan Sultan Idris, Perak, Malaysia

E-mail: gan.pt@fpe.upsi.edu.my 
Received: January 10, 2013

doi:10.5296/ber.v3i2.3881
Accepted: February 2, 2013

URL: http://dx.doi.org/10.5296/ber.v3i2.3881

\begin{abstract}
This study aims to analyze the long-term relationship and causal relationship between macroeconomic variables and passenger vehicle sales in Malaysia. In this study, the monthly time series data from April; 2004 to December; 2010 is used. To achieve the objectives, the Vector Autoregressive (VAR) estimation method is applied. Results show that there is no significant long-term equilibrium relationship between sales of passenger vehicles with macroeconomic variables. For the short term, only significant IPI variable affects the growth of passenger vehicle sales in Malaysia.
\end{abstract}

Keywords: Passenger Vehicle Sales, Macroeconomic, VAR

\title{
1. Introduction
}

Passenger vehicle is a part of the important transportation to the world now. It serves in smooth mobility of people and goods from one destination to another destination. Through efficient transportation infrastructure, economic activities involving local and foreign business can be conducted quickly and minimize the financial cost. According to Abu-Eisheh and Mannering (2002), the demand for vehicles will determine the pattern of travel, tourism, road design and housing. Therefore, transportation is an important factor for economic development of a country today.

In addition, according to Sean et al. (2003), the hierarchical position of the demand for vehicles comes second after the property demand among the people in the United States. This scenario occurs in many countries of the world including Malaysia. This can be proven by two circumstances. Firstly, the ratio of bank loans especially for car loan until 2010 which represents $13.3 \%$ of the total loan amount, demonstrates a double increase as compared to $6.7 \%$ in 1996 (BNM, 2010). Secondly, the total number of vehicles sold in the market in Malaysia has shown an increase of $262 \%$ or an average of $12 \%$ per annum for the period from 1990 to 2011. The increase in car sales is as shown in Figure 1.

Figure 1: Passenger Vehicle Sales in Malaysia (1990-2011).

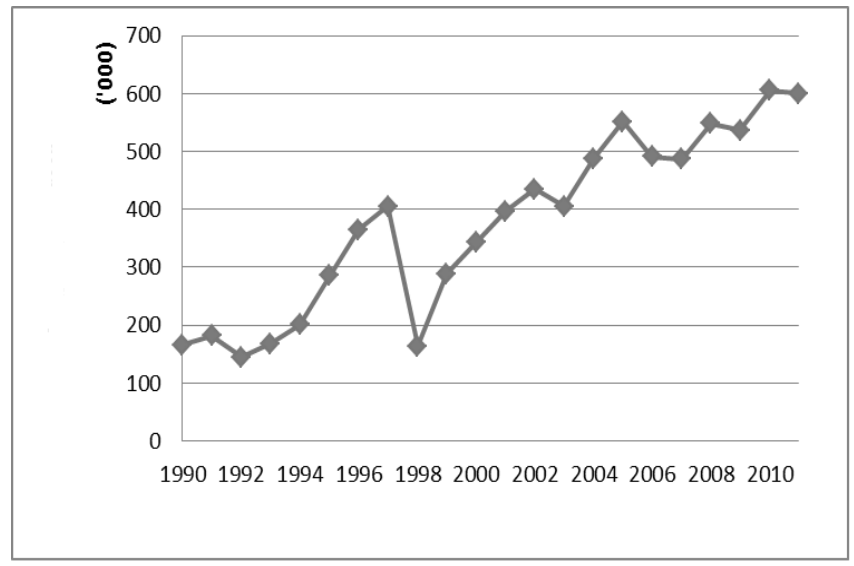


Source: Malaysian Automotive Association (MAA)

Figure 1 shows the total vehicle sales in 1990 amounted to 165,861 units, later it increased to 343,173 units in 2000 . Total sales continually increased from year to year. In 2011, the number of vehicles sold amounted to 600,123 units. Although the figure of vehicle sales indicated an increase as a whole, it was also affected by the current economic situation. The economic crisis in Asia in 1997/98 for instance, also gave negative implications on Malaysia's vehicle sales which had decreased by $60 \%$ than the previous year.

Due to the fluctuations that occur in the economy, it also has implications for the economic growth. This is because, the automotive sector in Malaysia is the sector that has contributed significantly to the economic policy changes in Malaysia, particularly in achieving the economic status of high-income by 2020 . The sector has accounted for $11 \%$ to $13 \%$ of economic value added to the manufacturing industry. In addition, the number of employment in the automotive sector has also nearly doubled in a decade from 2000 to 2009. (NPC, 2009; Wad and Govindaraju, 2011). During the economic crisis in the United States in 2008, the Malaysian government has established the Automotive Development Fund totaling to RM200 million to consolidate and rationalize the PROTON vendor system for the purpose of promoting exports and financing the easy loan scheme to vendors. Besides that, the scrapping scheme for vehicle over the age of 10 years was also implemented to promote car sales (Annual Report of the Malaysian Economy 2009/2010,p.14).

Over the factor of vehicle importance in daily business facilities for the community and also the country's economic growth, the study focuses on the macro analysis of relevant variables that affect the total passenger vehicles sales in the long term and short term.

The writing of this study is arranged as follows. The second section describes the literature review related to the topic of study, followed by a description of the data and research methodology in the third and the fourth. In the fifth part, the findings will be discussed and the conclusion of the study is discussed in the sixth.

\section{Literature Review}

Studies on the relationship between macroeconomic variables vehicle sales are very limited. However, there are few studies that have examined the impact of oil prices on car sales. According to Hamilton (1988) and Pindyck and Rotemberg (1984), the increase in the oil prices has increased the cost of operation for some durable goods. This will directly affect the demand for goods and investment, particularly for the automotive sector.

This study is supported by Lee and Ni (2002) research, that involves 14 industrial countries. They have seen the impact of oil prices through two aspects of supply and demand. On the supply side, it appears that the oil based manufacturing industry have been affected by the rising of oil prices as compared to other industries. Among the identified industries affected by these changes is the automotive industry. On the demand side, rising oil prices and their impact on production has resulted in inflation. This situation indirectly causes reduced consumer real income which will eventually reduce the demand for vehicle. 
The study by Barber et al. (1999) also examined the relationship between oil prices and foreign exchange rates on the sale of vehicles manufactured by the United States and Japan. The study found that both variables are significant to the sale of vehicles produced. However, it was found that the rise in oil prices gave more negative implications to the U.S. car production than the Japanese production. Justification to this situation is based on the focus of the automotive manufacturing market. The target of manufacturers in the United States is to produce vehicles in the luxury category as opposed to Japanese manufacturers. This situation has given market advantage (market gains) to Japanese manufacturers. Despite of the rising oil prices and affecting the demand, the impact suffered by the Japanese manufacturers is smaller.

The finding of this study is in line with Duncan (1980) who found that the increase in oil prices results in an increasing demand for small-sized vehicles that use less fuel. A study by Shahabudin (2009) through regression analysis using macroeconomic variables and monetary aggregates found that all the variables are significantly influenced by either vehicle sales of locally produced vehicles and imported. However, the findings of this analysis have serial correlation problems that stir the model consistency.

A study by Ludvigson (1998) is more focused on the impact of monetary policy on the sale of vehicles proxied by bank loan supply for automobile loans. The increase in interest rates was found to have negative implications. This is because the ability of banks to provide more loan offers was reduced due to the change in monetary policy.

A study by Dargay and Gately (1999) on the impact of income on car ownership in 26 countries for the period 1960 to 1992 found that, estimation of vehicle ownership for the past two decades through 2015 is high for low-income countries. Whereas, for the countries of China, India and Pakistan, the ownership of the vehicle doubled in line with the growth in per capita income.

In Dargay's study (2001) in the UK using data from the Family Expenditure Surveys 1970 and 1995, found that the ownership of the vehicle increases if income is also increased. However, this situation is not consistent in the event of a decline in income. This condition is associated with a person's behavior and the difficulty to change as the vehicle is now becomes a necessity in life.

In Malaysia, studies analyzing the relationship between vehicle sales with macroeconomic variables using econometric approach are also very limited. Many previous studies conducted were more focused on qualitative discussion regarding the development of the automotive sector in Malaysia. As an example in Ward and Govindaraju (2011) and Mohd Rosli (2006). Therefore, this study can be considered as a preliminary study aimed to explore the extent of these macroeconomic variables relating to the sales of passenger vehicles, particularly in Malaysia. Given no specific studies done to examine this relationship, the objective of this study is looking at the long-term equilibrium relationship and the Granger causal relationship between sales of passenger vehicles with macroeconomic variables in Malaysia.

\section{Description of Data}

In this study, five variables are used for the analysis section. Definitions for each of the 
variables used are outlined in Table 1

Table 1. Definition of research variables

\begin{tabular}{|c|c|c|c|}
\hline No & Variable & Description & Source \\
\hline 1 & $\begin{array}{l}\text { Sales of passenger } \\
\text { vehicles (CAR) }\end{array}$ & $\begin{array}{l}\text { CAR is the number of passenger vehicles sold in } \\
\text { Malaysia }\end{array}$ & MAA, UPE \\
\hline 2 & $\begin{array}{ll}\text { Consumer } & \text { Price } \\
\text { Index }(\mathrm{CPI}) & \\
\end{array}$ & CPI is used as a proxy to the inflation & BNM \\
\hline 3 & $\begin{array}{l}\text { Index of Industrial } \\
\text { Production (IPP) }\end{array}$ & $\begin{array}{l}\text { IPP is used as a proxy to the Gross domestic product } \\
\text { (GDP) }\end{array}$ & BNM \\
\hline 4 & $\begin{array}{l}\text { Oil Price } \\
\text { (OIL) }\end{array}$ & $\begin{array}{l}\text { OIL is used as a proxy to the oil price sold at gas stations } \\
\text { in Malaysia. the price is based on car oil of RON92 } \\
\text { (currently RON95) }\end{array}$ & $\begin{array}{l}\text { Ministry of Commerce } \\
\text { and Consumer Affairs }\end{array}$ \\
\hline 5 & $\begin{array}{l}\text { Monetary Policy } \\
\text { Rate (ONR) }\end{array}$ & $\begin{array}{l}\text { ONR is used as a proxy for the country's monetary } \\
\text { policy. This rate determines the interest rate of loans } \\
\text { offered by banking institutions. }\end{array}$ & BNM \\
\hline
\end{tabular}

In this study, the time series of monthly data from April 2004 to December of 2010 is used. The choice of this period is based on the availability of the monthly vehicle sales data reported by the Economic Planning Unit, Malaysia. For the purpose of analysis, the CAR, CPI and IPI variables are transformed in log form. Regression model for this study is based on the model of aggregate demand vehicles. This model has been applied in the study of Duncan (1980), Shahabudin (2009) and Lee and Ni (2002). Regression models to examine the relationship can be summarized as follows:

$$
\mathrm{CAR}=\mathrm{f}\{\mathrm{CPI}, \mathrm{IPP}, \mathrm{OIL}, \mathrm{ONR}\}
$$

Model in equation (1) is regressed in log-linear form which is written as follows:

$$
L N C A R_{t}=\alpha_{1} L_{N C P I}+\alpha_{2} L N I P P_{t}+\alpha_{3} L N O I L_{t}+\alpha_{4} L N O N R_{t}+\varepsilon_{t}
$$

Based on the standard VAR estimation method, the model of the above equation containing these five variables can be rewritten as follows:

$$
\left[\begin{array}{l}
C A R_{t} \\
C P I_{t} \\
I P P_{t} \\
O I L_{t} \\
O N R_{t}
\end{array}\right]=\left[\begin{array}{l}
A_{1} \\
A_{2} \\
A_{3} \\
A_{4} \\
A_{5}
\end{array}\right]+R(L)\left[\begin{array}{l}
C A R_{t-1} \\
C P I_{t-1} \\
I P P_{t-1} \\
O I L_{t-1} \\
O N R_{t-1}
\end{array}\right]+\left[\begin{array}{l}
e t_{1} \\
e t_{2} \\
e t_{3} \\
e t_{4} \\
e t_{5}
\end{array}\right]
$$

Where $\mathrm{R}$ is a 5 x 5 matrix polynomial estimator parameters, (L) is the lag operator, A is the intercept and et is the Gaussian error vector with zero mean and variance matrix $\Omega$.

\section{Research Methodology}


For the purpose of analyzing the long term and short term causal relationship between the passenger vehicle sales variable and the macroeconomic variables, the method of vector autocorrelation (VAR) was applied. To get the good results of the analysis, the standard procedure of time series data analysis was conducted.

Stationarity test of variables series using the Augmented Dickey-Fuller (ADF) and Phillips-Perron (PP) was conducted as the first step to find out whether all study variables have the same degree of integration or different. Degree of integration is essential to enable further analysis to be undertaken. In addition, the same level of integration also shows the possibility of long-term causal relationship, known as cointegration.

The next step is to determine the appropriate lag before applying model-based cointegration method of Johansen (1988) and Johansen and Juselius (1990) or to simplify the J \& J. To ensure that the selected lag is appropriate, the test of the VAR unit stability was implemented. The next step is the cointegration analysis based on the $\mathbf{J} \& \mathbf{J}$ method called Multivariate Johansen Test. This method aims to ensure that the relationship of the series of variables studied exist in the long term. The determination of the existence of this relationship is seen on the significant value for the two types of statistical value which is the Trace statistical value and Eigen maximum value.

To obtain the mutual relationship between the variables that is known as the causal short-term relationship, the method of vector error correction model-VECM was applied. This method can describe the variables analyzed whether it is exogenous or otherwise.

\section{Result of Empirical Analysis}

Discussion on the data analysis results obtained based on the VAR testing procedures initiated by the unit root test analysis results, followed by cointegration test and ended with a vector error correction model.

\subsection{Stationarity Test}

Stationarity analysis or also known as integration test was done to investigate the stationarity degree of each variable. It should be done in advance to avoid the occurrence of spurious regression problem. This study requires the same degree of immobilization for each time series as it is a prerequisite in cointegration analysis and Granger causal VECM version.

Table 2 shows the results of the analysis of stationarity tests using ADF and PP. Based on Table 2 , it appears that all variables in the study had the same integration or stationarity level of I (1).

Table 2. Unit Root Test

\begin{tabular}{|c|c|c|c|c|}
\hline Variable & $\begin{array}{c}\text { ADF } \\
\text { (level) }\end{array}$ & $\begin{array}{c}\text { ADF } \\
\text { (First differentiation) }\end{array}$ & $\begin{array}{c}\text { PP } \\
\text { (level) }\end{array}$ & $\begin{array}{c}\text { PP } \\
\text { (First differentiation) }\end{array}$ \\
\hline CAR & 0.3103 & $-9.6479^{*}$ & 0.3815 & $-17.1546^{*}$ \\
\hline CPI & 2.3495 & $-5.4047^{*}$ & 3.0213 & $-5.3991^{*}$ \\
\hline IPP & 1.0726 & $-2.0174^{*}$ & 0.4660 & $-20.8352^{*}$ \\
\hline OIL & 0.2423 & $-7.8217^{*}$ & 0.2423 & $-7.8259^{*}$ \\
\hline ONR & -0.3147 & $-4.5939^{*}$ & -0.2537 & $-4.5760^{*}$ \\
\hline
\end{tabular}


* Significant at $1 \%$ significance level.

\subsection{Lags Selection}

Based on the method of estimation of vector autoregressive (VAR), the selection of the correct lag is important to ensure that the findings reflect the real economic situation and in line with economic theory and econometrics (Ibrahim, 2007)

Table 2. Lags Test

\begin{tabular}{|c|c|c|c|}
\hline Lags & $\begin{array}{c}\text { Final Prediction Error } \\
(\text { FPE })\end{array}$ & $\begin{array}{c}\text { Akaike Information Criterion } \\
\text { (AIC) }\end{array}$ & $\begin{array}{c}\text { Schwarz Information Criterion } \\
\text { (SIC) }\end{array}$ \\
\hline 0 & $2.59 \mathrm{e}-10$ & -7.8858 & -7.7336 \\
\hline 1 & $1.50 \mathrm{e}-14$ & -17.6453 & $-16.7322^{*}$ \\
\hline 2 & $7.05 \mathrm{e}-15^{*}$ & $-18.4063^{*}$ & -16.7321 \\
\hline 3 & $8.50 \mathrm{e}-15$ & -18.2040 & -15.8052 \\
\hline
\end{tabular}

* show the lags selected by the criteria are based on the minimum value

Based on Table 3, criteria of Final Prediction Error (FPE) and the Akaike Information Criterion (AIC) suggest that the selected lags are lags 2, while the Schwarz Information Criterion (SIC) was chosen based on the lags of 1 to the smallest value for each criterion. However, this study will only be using the Akaike Information Criterion (AIC) in selecting the lag of lags 2. The selection of lags that uses these criteria in previous studies is the same as the study by Adam and George (2008) and Yusoff et al. (2006). Therefore, the lag two (2) will be used to test the cointegration and vector error correction model (VECM).

\subsection{The VAR Stability Test}

Among the important features in VAR analysis is the VAR (p) - variable that can produce a stable process. Stable VAR process is important because it produces an efficient model in terms of analysis of variance, covariance and also the beginning of the analysis period. VAR stability is achieved if the value of the modulus obtained is less than one. If VAR is not stable, the solution can be done is to reduce the time lags (Charemza and Deadman 1997, Gujarati 2003). Results of this analysis are shown in Table 4.

Table 4. VAR Unit Polynomial Stability Test

\begin{tabular}{|l|l|}
\hline Unit & Modulus \\
\hline 0.995051 & 0.995051 \\
\hline $0.845294-0.091717 \mathrm{i}$ & 0.850256 \\
\hline $0.845294+0.091717 \mathrm{i}$ & 0.850256 \\
\hline $0.540139-0.407871 \mathrm{i}$ & 0.676837 \\
\hline $0.540139+0.407871 \mathrm{i}$ & 0.676837 \\
\hline 0.670566 & 0.670566 \\
\hline$-0.494558-0.203829 \mathrm{i}$ & 0.534915 \\
\hline$-0.494558+0.203829 \mathrm{i}$ & 0.534915 \\
\hline-0.339778 & 0.339778 \\
\hline 0.184408 & 0.184408 \\
\hline
\end{tabular}

Based on Table 4, it was found that the modulus obtained is smaller than one. This shows that 
the analysis is stable. Therefore, the selected lag two (2) is sufficient.

\subsection{Cointegration Analysis}

Based on the findings of the analysis shown in Table 2 showing that the series of variables have the same degree of integration, the cointegration test was implemented. This test result analysis is shown in Table 5.

Table 5. Cointegration Test

\begin{tabular}{|c|c|c|c|c|c|}
\hline Model & Null Hypothesis & Trace Statistics & $\begin{array}{c}\text { Critical Value } \\
(5 \%)\end{array}$ & $\begin{array}{c}\text { Maximum Eigen } \\
\text { Statistics }\end{array}$ & $\begin{array}{c}\text { Critical Value } \\
(5 \%)\end{array}$ \\
\hline Lag $: 2^{\#}$ & $\mathrm{r} \leq 0$ & $96.0375^{*}$ & 69.8188 & $40.5145^{*}$ & 33.8768 \\
\cline { 2 - 6 } & $\mathrm{r} \leq 1$ & $55.5230^{*}$ & 47.8651 & $32.9616^{*}$ & 27.5843 \\
\cline { 2 - 6 } & $\mathrm{r} \leq 2$ & 22.5614 & 29.7907 & 16.3253 & 21.1316 \\
\cline { 2 - 6 } & $\mathrm{r} \leq 3$ & 6.2360 & 15.4947 & 6.0497 & 14.2646 \\
\hline
\end{tabular}

* Significant at 5\% significance level.

critical value is obtained from Osterwald-Lenum (1992)

\# Lags is based on AIC value

Based on Table 5, it is found that there are at least two cointegration relationship obtained. This shows that there are two equations that may be developed in the long term. Based on the results of this cointegration, long-term relationship that has been transformed in the form of the normal equations for passenger vehicle sales in Malaysia with macroeconomic variables can be written as shown in Table 6.

Table 6. Cointegration Relationship

\begin{tabular}{|c|c|c|c|c|c|}
\hline \multirow{2}{*}{ Dependent variable (LNCAR) } & \multicolumn{5}{|c|}{ Independent Variable } \\
\cline { 2 - 6 } & LNCPI & LNIPP & OIL & ONR & C \\
\hline Coefficient & -0.0452 & 0.7089 & -0.1065 & -0.1266 & -7.8915 \\
\hline s.e value & $(0.8207)$ & $(0.5747)$ & $(0.1563)$ & $(0.0640)$ & \\
\hline
\end{tabular}

* Significant at $1 \%$ significance level.

Based on Table 6, it appears that CPI, OIL and ONR variables are negatively related, while the IPPs are not. Although, these variables are in line with the theory and also with the findings of previous studies, but it is not significant. The question now is, does the passenger vehicle sales variable is the independent variable (exogenous) or dependent (endogenous)? To answer this question, the method of vector error correction model (VECM) is applied.

\subsection{Analysis of Vector Error Correction Models (VECM)}

Based on the cointegration test shown in Table 6, it is proven that the existence of a long-term relationship between the variables-variables in the study is of the same degree of integration. Hence, the term of error correction (ECT) should be included in the model before testing the Granger causal relationship can be carried out. Engle and Granger (1987) and Toda and Phillips (1993) argue that the failure to take into account the error correction term (ECT) will result in the test conducted produces specification error model (model misspecification). Therefore, the Granger causality test should be expected in the vector error correction model (VECM) version and the results are shown in Table 7. 


\section{Macrothink}

Table 7. Vector Error Correction Model (VECM) test

\begin{tabular}{|c|c|c|c|c|c|c|}
\hline \multirow{2}{*}{ Dependent Variables } & \multicolumn{5}{|c|}{ Independent Variable } & t- statistics value \\
& \multicolumn{7}{|c|}{ Chi-Square Value (Wald test) } & \\
\cline { 2 - 7 } & $\Delta$ LNCPI & $\Delta$ LNIPP & $\Delta$ OIL & $\Delta$ ONR & $\Delta$ LNCAR & Ect-1 \\
\hline$\Delta$ LNCPI & & 0.0541 & 3.6518 & 0.7249 & 0.7299 & $0.0046(0.0067)$ \\
\hline$\Delta$ LNIPP & $6.5342 * *$ & & $12.7820^{*}$ & 0.0658 & 2.8863 & $-0.0959 *(0.0511)$ \\
\hline$\Delta$ OIL & 4.0849 & 0.8742 & & 0.9681 & 3.4444 & $-0.0730(0.0408)$ \\
\hline$\Delta$ ONR & $10.6819 *$ & 0.8019 & 3.9030 & & 1.1005 & $-0.1859(0.1463)$ \\
\hline$\Delta$ LNCAR & 2.5426 & $8.8054^{* *}$ & 1.3943 & 0.1230 & & $-0.5659 *(0.1413)$ \\
\hline ***,*** Signficant at significance level of 1,5 and $10 \%$ \\
( ) s.e value
\end{tabular}

Based on Table 7, long-term Granger causal relationship can be seen on the ECT-1 for each variable. Based on the VECM test results, it is found that the ECT-1 CAR and IPI variables are significant. This variable indicates that the CPI, the IPI, OIL and ONR are long-term Granger causal to CAR, while the CPI, ONR, CAR OIL are for the IPP variable.

The result from the ECT value on the CAR variable in particular clearly shows that the CAR variable in the equation carries the error correction burden of scattered short-term balance to strike a balance in the long term. This suggests that the CAR variable is endogenous variables in the study model. Coefficient ECT-1 also reflects the speed of adjustment to achieve a balance in the long-term in which the value is -0.5659 that means as much as 56.59 percent of the adjustment is done during the lags two to achieve long-term equilibrium.

From Table 8 also, a short-term causal relationship is obtained based on the Wald test. Test results reveal that the CPI is a short-term causes of the IPP, and OPR, while the OIL is the short-term cause to IPPs. For CAR variables, only the IPI is found to have a short-term relationship.

Overall, the direction design of Granger causal short-term relationship can be summarized as shown in Figure 2 below.

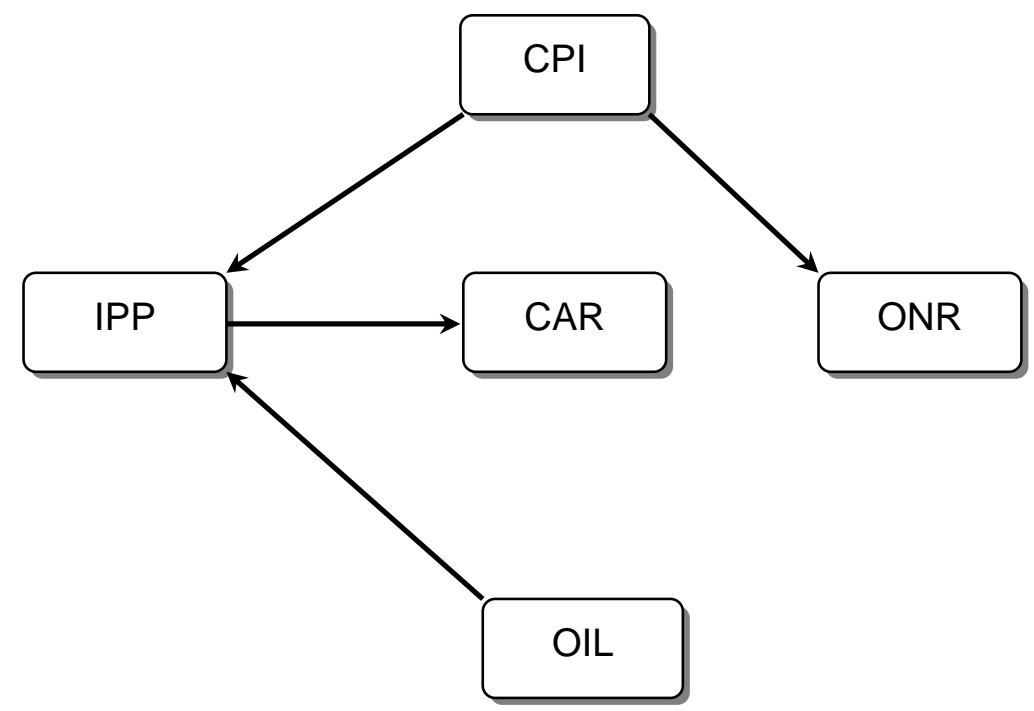

Indicator:

$\longrightarrow$ One way relationship $\longleftrightarrow$ two way relationship

Figure 2. Causal Relationship 


\section{Mll Macrothink}

Business and Economic Research ISSN 2162-4860 2013, Vol. 3, No. 2

Based on Figure 2, it can be concluded that there are two pathways that affect auto sales in Malaysia in the short term. The first route is OIL-IPP-CAR, while the second path is the CPI-IPI-CAR. From the first line, it is in line with the findings of previous studies that found that changes in oil prices will affect the demand for cars. This can be attributed to the net income of users will be affected in the event of rising oil prices. Apart from the oil price factor, the increase in overall inflation will also affect the consumer income. Thus, the main factor affecting the automotive sales in Malaysia is the income. For that reason, factors that can affect this income will directly affect the automotive sales.

\section{Conclusion}

This paper analyzes the relationship between macroeconomic variables with auto sales in Malaysia for the period of 2004: M4 to 2010 : M12 by using the VAR method. From the analysis results obtained, it appears that there are two pathways that influence the sales of passenger vehicles in Malaysia, which are the CPI variables to the IPP and secondly the OIL variables to the IPP. Shocks that occurr on IPP variables are found to affect the sales of passenger vehicles in Malaysia. This indicates that the sale is dependent on the economic level which is a proxy for the measurement of consumer income. Good income position will affect positively to the increasing demand for passenger vehicle sales in Malaysia. Therefore, to improve the automotive sector in Malaysia, the government should ensure that the level of income of the users in Malaysia to remain strong and not be adversely affected by factors such as rising prices, oil and so on.

\section{Acknowledgements}

The research is financed by Internal Short-Term Grant by RMIC-UPSI, Perak, Malaysia.

For ASEAN automotive relationship already published in IOSR Journal of Business and Management (IOSRJBM), Vol. 2, Issue 1 (July-Aug 2012).

\section{Reference}

Abu-Eisheh, S. A., \& Mannering, F. L. (2002). Forecasting automobile demand for economics in transition: a dynamic simultaneous equation system approach, Transportation Planning and Technology, 25(4), 311-31. http://dx.doi.org/10.1080/0308106022000019026

Adam, A. M, \& George T. (2008). Do macroeconomic variables play any role in the stock market movement in Ghana?. Munich Personal RePEc Archive (MRPA). No. 9357, 1-21. http://dx.doi.org/10.2139/ssrn.1152970

Brad M. Barber, Reid W. Click, \& Masako N. Darrough. (1999). The impact of shocks to exchange rates and oil prices on U.S sales of American and Japanese automakers, Japan and the World Economy, 11, 57-93. http://dx.doi.org/10.1016/S0922-1425(98)00041-3

Charemza, W., \& Deadman, D. (1997). New Directions in Econometric Practice : General to Specific Modelling, Cointegration, and Vector Autoregression, Edward Elgar Pub., Lyme, N.H. 
Cheung, Y-W., \& Lai, K. (1993). A fractional cointegration analysis of purchasing power parity, Journal of Business \& Economic Statistics, 11, 103-112. http://dx.doi.org/10.2307/1391310, http://dx.doi.org/10.1080/07350015.1993.10509936

Engle, R. F., \& C. W. J. Granger. (1987). Cointegration and error correction: representation, estimation and testing, Econometrica, 55, 251-276. http://dx.doi.org/10.2307/1913236

Gujarati, D. N. (2003). Basic Econometrics, McGraw Hill, Boston.

Hamilton, J. D. (1988). A neoclassical model of unemployment and the business cycle. Journal of Political Economy, 96, 593-617. http://dx.doi.org/10.1086/261553

Ibrahim, M. (2007). The Role of Financial Sector in Economic Development: The Malaysian Case, International Review of Economics, 5(4), 463-483. http://dx.doi.org/10.1007/s12232-007-0023-4

Johansen, S, \& K. Juselius. (1990). Maximum Likelihood Estimation and Inferences on Cointegration With Application to The Demand For Money, Oxford Bulletin of Economics and Statistics, 52, 169-210. http://dx.doi.org/10.1111/j.1468-0084.1990.mp52002003.x

Johansen, S. (1988). Statistical Analysis of Co-Integration Vectors, Journal of Economic Dynamics and Control, 12, 231-254.

Joyce, M. D. (2001). The effect of income on car ownership: evidence of asymmetry, Transportation Research Part A, 807-821. http://dx.doi.org/10.1016/S0965-8564(98)00026-3

Joyce, M. D., \& Detmot, G. (1999). Income's effect on car and vehicle ownership, worldwide: 1960-2015, Transportation Research Part A, 33,101-138.

Kiseok, L., \& Shawn, N. (2002). On the dynamic effects of oil shocks: a study using industry level data, Journal of Monetary economics, 49, 823-852.

Mohd Rosli, (2006). The Automobile industry and Performance of Malaysian Auto Production, Journal of Economic Cooperation, 27(1), 89-114.

Pindyck, R. S. \& Rotemberg, J. J. (1983). Dynamic factor demands and the effects of energy price shocks, American Economic Review, 73, 1066-1079.

Roger, S. D. (1980). The Effect of Gasoline Prices on Automobile Sales, The American Economist, 24(1-Spring), 62-66.

Sean, P. McAlinden, Kim Hill \& Bernand Swiecki (2003). Economic Contribution of the Automotive Industry to the U.S Economy-An Update, A report for the Alliance of Automobile Manufacturers, Center for Automotive Research (CAR), 1-47.

Sydney, L. (1998). The Channel of Monetary Transmission to Demand: Evidence from the Market for Automobile Credit, Journal of Money, Credit and Banking, 30(3), 365-383. http://dx.doi.org/10.2307/2601106 


\section{Macrothink}

Business and Economic Research

ISSN 2162-4860 2013, Vol. 3, No. 2

Syed Shahabudin, (2009). Forecasting automobile sales, Management Research News, 32(7), 670-682. http://dx.doi.org/10.1108/01409170910965260

Toda, H. Y., \& Phillips, C. B. (1993). Vector Autoregressions and Causality, Econometrica, 61, 1367-1393. http://dx.doi.org/10.2307/2951647

Wad, P., \& Govindaraju, V. G. R. C. (2011). Automotive industry in Malaysia: an assessment of its development, Int. J. Automotive Technology and Management, 11(2), 152-171. http://dx.doi.org/10.1504/IJATM.2011.039542

Yusoff, R. M, Majid, M. S. A, \& Razali, A. N. (2006). Macroeconomic Variables and Stock Returns in the Post 1997 Financial Crisis: An Application of the ARDL Model, Paper presented in $6^{\text {th }}$ Global Conference on Business \& Economics, Gutman Conference Center, USA, 15-17 October 2006.

\section{Copyright Disclaimer}

Copyright reserved by the author(s).

This article is an open-access article distributed under the terms and conditions of the Creative Commons Attribution license (http://creativecommons.org/licenses/by/3.0/). 